Economics in Literature and Drama

Author(s): Michael Watts and Robert F. Smith

Reviewed work(s):

Source: The Journal of Economic Education, Vol. 20, No. 3 (Summer, 1989), pp. 291-307

Published by: Taylor \& Francis, Ltd.

Stable URL: http://www.jstor.org/stable/1182306

Accessed: 14/03/2012 01:55

Your use of the JSTOR archive indicates your acceptance of the Terms \& Conditions of Use, available at http://www.jstor.org/page/info/about/policies/terms.jsp

JSTOR is a not-for-profit service that helps scholars, researchers, and students discover, use, and build upon a wide range of content in a trusted digital archive. We use information technology and tools to increase productivity and facilitate new forms of scholarship. For more information about JSTOR, please contact support@jstor.org. 


\section{Economics in Literature and Drama}

\section{Michael Watts and Robert F. Smith}

The prophet and the poet may regenerate the world without the economist, but the economist cannot regenerate it without them.

Philip Wicksteed

The Commonsense of Political Economy

It has long been noted that although literature and drama, like language, function as institutions in some ways separate from economic forces and conditions, they do play an important role in shaping public opinion and standards on many economic issues. ${ }^{1}$ In turn, economic thought and circumstances help shape and direct literature, drama, and language. It is surprising, then, that few economists have carefully studied these influences.

This inattention may stem from the observation that many literary works are decidedly antimarket and even anti-economics in terms of rejecting the method Keynes described as the economic way of thinking. Perhaps in response to this, economists have tended to dismiss the analytical skills of literary authors out of hand, suggesting that bias pervades most of their works dealing with economic matters. In a survey of such works, however, we found a surprising number that describe analytical economic concepts accurately. Furthermore, although there is much agreement in these works concerning appropriate forms of individual economic behavior, disagreement over policy and overall forms of social organization related to economic questions is not unlike that which exists within the economics profession.

In the following two sections, we describe how economists have typically used literary works and viewed their authors. The next section provides a selection of literary treatments of economic concepts, issues, and themes, suggesting a rich vein of largely untapped material for high school and university economics instructors. In the final section, we offer our conclusions on the scope and diversity of these literary materials.

\section{THE ECONOMISTS AND THE AUTHORS}

From the time that Thomas Carlyle labeled economics the dismal science, the relationship between literature and economics has been uneasy, usually characterized by ambivalent toleration. In some periods and with certain

Michael Watts is an associate professor of economics at Purdue University, and Robert $\boldsymbol{F}$. Smith is a professor of economics at the University of Nevada-Las Vegas. 
authors, outright disdain for the methods of the other field has been expressed by prominent representatives of both disciplines. Stigler (1982, pp. 27-29) describes one such exchange involving the poet laureate Robert Southey and Thomas Babington Macaulay and offers roughly contemporary passages from Carlyle and John Ruskin that join in Southey's antiindustrial, anticompetitive stance. Many modern economists are interested in cross-disciplinary work, however, with some borrowing from and intruding into fields such as anthropology, psychology, sociology, biology, ethics, philosophy, and law, as well as literature. ${ }^{2}$

Economists are often struck by the activist orientation to political economy adopted by many literary authors, especially by those with a liberal stance, like the "muckrakers." In addition to writing exposés of unwholesome practices in particular industries, such as Upton Sinclair's The Jungle, authors have criticized monopoly power, employment practices, and income distribution. Such themes are especially prevalent and well known in the works of American authors who wrote early in this century, such as Frank Norris, John Steinbeck, John Dos Passos, and William Faulkner. In their recent film series and book Free to Choose (1980), Milton and Rose Friedman attribute significant influence to literary writers in the shaping of current attitudes on income distribution schemes. ${ }^{3}$

Although it is customary to view the political economy that is at least implicitly behind most modern literature as liberal, Ayn Rand's work shows that an activist and conservative political economy may also be developed through literary devices. Earlier works by Benjamin Franklin, Horatio Alger, and even Ralph Waldo Emerson may be less activist in the modern sense, but they are certainly conservative from both the traditional and modern perspectives.

Questions of the alleged political and economic biases of authors have also attracted a considerable amount of attention when economic historians have attempted to use literary passages to establish their own ideas concerning economic conditions or levels of economic activity. In traditional economic histories, it is common to find passages from poems, novels, and plays cited as evidence that some particular industrial practice had been introduced at a certain time or place, or that living standards had changed. This sort of reference is found most often in works that deal with earlier centuries. Probably more economic histories of sixteenth-century England than not refer to the spinning mills in Thomas Deloney's Jack of Newbery. ${ }^{4}$ Much more controversial is the extensive debate over the proper interpretation and use of literature describing the standard of living during the period of the English Industrial Revolution. ${ }^{5}$

With respect to the history of economic thought, the works of Swift, DeQuincy, Coleridge, Southey, Peacock, Carlyle, Ruskin, Dickens, Cobbett, and Bellamy, among others, have received some attention in numerous theses and other scholarly publications. ${ }^{6}$

Studies on how literary authors have anticipated, synthesized, or contributed to the development of economic analysis are rare. It is not unusual, 
however, to see Gresham's law attributed to Aristophanes (Spiegel 1971, p. 688), and Henry W. Farnam, a professor of economics at Yale, was admitted to Yale's Elizabethan Club for his work "Shakespeare As An Economist."7

\section{ECONOMISTS' USE OF LITERATURE}

Popular opinion notwithstanding, some economists have a sense of humor often exercised by the use of literary devices. John Kenneth Galbraith's most obvious satire was published under the pen name Mark (from Mark Twain) Epernay (Galbraith 1963). More recently, two economists took the pen name Marshall Jevons to have some fun, in a series of mystery novels, with the "unbreakable" laws of economics, and other economists have since followed suit.

It is much more common to find economists introducing their papers or chapters in books with short quotations from literary works. This approach is especially popular in textbooks, perhaps because Paul Samuelson's influential book established a precedent in this respect. A few recent textbooks have gone even further and devote entire pages to literary excerpts related to some economic theme, issue, or concept. ${ }^{8}$ At least two prominent economists, William Stanley Jevons and Kenneth Boulding, have included their own poetry in their professional economic works.

Some cynics, perhaps recalling Adam Smith's thoughts on vanity or Veblen's on conspicuous leisure, might suggest that economists who resort to literary allusions are only flaunting their own erudition. Nevertheless, such references can be fun, and they may even contribute to the substantive points in question. For example, in making a plea for the quick imposition of wage and price controls several years ago, an economist cited Macbeth's warning:

If it were done when 'tis done, then 'twere well It were done quickly

A respondent pointed out that in that passage Macbeth is discussing the murder of Duncan, Macbeth's king, kinsman, and houseguest. Extending the allusion, the respondent argued that wage and price controls might be viewed as the murder of the market economy-a step most economists are not prepared to take, given the many benefits of the market system. Or, as Lady Macbeth says, "Yet who would have thought the old man to have had so much blood in him?"

In "Shakespeare vs. Becker on Altruism: The Importance of Having the Last Word" (1979), Jack Hirshliefer responded to an article on Gary Becker's theory of altruism. Hirshliefer's comment featured indifference curves, a transfer line, and a joint production-income opportunity frontier, but it began with a three-line quotation from King Lear. Becker thanked Hirshliefer "for finding such a formidable protagonist" as Lear and asked, "Can economics now be extended to literature as well?" (1977, p. 507). 
The most prestigious indication that literary passages can be useful to professional economists in their own work, by being fun and by providing clear, nontechnical examples of economic concepts, has been the practice of the Journal of Political Economy of often reprinting literary passages on its back cover..$^{9}$ This practice was begun in 1973, the year that Stigler was named a coeditor of the journal.

Some university and high school instructors have developed instructional units based on literary passages with substantial economic content. ${ }^{10}$ The objectives of this approach include (1) reaching new groups of students who find the study of economics boring and distasteful; (2) providing interesting and complementary materials to supplement textbooks and other instructional materials; and (3) adding to the instructor's own store of examples, stories, and allusions. The success of such efforts depends on the available quantity, quality, and variety of suitable passages. We devote the remainder of this paper to a partial survey of such passages. The Appendix provides a list of over fifty passages by various authors, including page references to selected editions of the works and indications of the major economic concepts or issues discussed.

\section{ECONOMICS IN LITERATURE}

If we begin with the idea that economics is the study of the allocation of scarce resources to satisfy unlimited wants, it is quite simple to find similar themes in literature. In John Milton's The Mask of Comus, for example, the disreputable speaker tempts a virgin by arguing that it would be ungrateful not to use available natural resources to satisfy human wants. In a very different setting, Emerson's Journals discusses human, natural, and capital resources (especially in England and Holland), and entrepreneurship (in terms of the fame and wealth that commonly go to those who "build a better mousetrap"). Literary authors are probably most aware of the potential of human resources, often in an explicitly economic setting. For example, F. Scott Fitzgerald's Gatsby carefully budgets his time to develop his human capital as a youth and then follows Daisy (whose voice is "full of money") in his pursuit of the American Dream. The young Gatsby is reminiscent of the young Ben Franklin (as depicted in Franklin's Autobiography and reflected in Poor Richard's Almanac), but the times and the men are different, and Gatsby's turn to the underworld hastens both his success and his downfall. The subject of labor resources often leads literary authors into discussions of economic systems, profits, labor unions, and income distribution; we will discuss these complex issues later.

In terms of more elementary concepts, prominent writers have recognized the general idea of opportunity costs outside of the narrow setting of budgeting, most clearly in Robert Frost's “The Road Not Taken." Frost's "Mending Wall" also considers another basic economic concept and institution, private property. It is interesting to read this poem with an eye to Frost's concern about the natural or artificial nature of private property, 
and the related concern of whether property should be maintained either as a matter of right or as a matter of efficiency and expediency ("Good fences make good neighbors"').

Many authors show a surprising concern about efficiency and things that can increase it, sometimes at a cost, such as specialization and the division of labor. The passages from Sherwood Anderson's Winesburg, Ohio dealing with the relationship between Wing Biddlebaum and George Willard are as balanced a discussion on the costs and benefits of specialization as we find in The Wealth of Nations. (Biddlebaum has special manual skills; Willard is a promising and skilled writer.) Reading several of the character sketches in Edgar Lee Masters' Spoon River Anthology produces a similar, if less balanced, picture. ${ }^{11}$ In Book 4 of The Dunciad, Alexander Pope has written some passages on specialization that are particularly relevant to social scientists. In Sister Carrie, Theodore Dreiser even recognized that specialization is limited by the extent of the market (chapter 30, "The Kingdom of Greatness: The Pilgrim Adream"').

Literary authors are also especially concerned with the role of entrepreneurs, both real and archetypal, in driving the process of growth and building up concentrations of economic power to be used for good or bad. John Dos Passos's U.S.A. trilogy includes sketches of Henry Ford and Andrew Carnegie, among others, and covers such topics as the productivity gains from Ford's assembly-line operations, the private philanthropy of these two industrial giants, and concerns about the military-industrial complex. There is also a sketch of Joe Hill, an early leader of the radical IWW, and a sketch of Thorstein Veblen entitled “The Bitter Drink." Joseph Heller's Catch-22 contains a more satirical portrait-Milo Minderbinder, an entrepreneur who functions with equal ease and success in open markets, traditional economies, and the often frustrating and uneconomic world of the wartime army. One has the feeling that Minderbinder would be just as comfortable operating with Fagin or other characters out of a Dickens novel.

The role of competitive markets in limiting the concentration and abuse of economic power is frequently discussed in literary works, as is the importance of using economic incentives to generate work, investment, and risk taking in a free society. The entrepreneurs mentioned clearly understand profits-Minderbinder even knows that you can make a profit buying eggs for seven cents and selling them for five, if you are buying them from yourself and originally paid a penny an egg. In Horace, and in Pope's "Imitations of Horace," a soldier charges a fortress in one battle to earn a share of prize money but is considerably less aggressive in later battles, given his new wealth. In Washington Irving's "The Poor-Devil Author," the title character is a renowned writer of high literature in his small hometown, but, when in London, he eventually discards his manuscript and begins writing anonymous pieces in trade journals, recognizing that by producing something in demand he can at least lead a comfortable, if not glamorous, life.

Some striking passages concerning free markets can be found in Mark Twain's A Connecticut Yankee in King Arthur's Court. In chapter 33, 
"Sixth Century Political Economy," the hero makes a valiant, but futile, attempt to instruct a group of workers on the difference between real and nominal wages and provides a strong defense of free trade that is, in some ways, reminiscent of Bastiat's petition from the candlemakers.

Considering markets in a more abstract sense, we find John Steinbeck's $\mathrm{Cal}$, in East of Eden, earning a profit by speculating in beans just before World War I. When his father asks him to return the money, he realizes that impersonal and automatic forces drove prices up. "Give it back to who?" Cal asks-a rather sophisticated question.

Frank Norris's The Octopus includes a straightforward passage dealing with the power, pervasiveness, and impersonality of market forces:

You are dealing with forces, young man, when you speak of Wheat and Railroads, not with men. There is the Wheat, the supply. It must be carried to feed the People. There is the demand. The Wheat is one force, the Railroad, another, and there is the law that governs them-supply and demand. Men have only little to do in the whole business. Complications may arise, conditions that bear hard on the individual-crush him maybe-but the Wheat will be carried to feed the people as inevitably as it will grow. (Norris 1958, p. 395)

Whereas Norris, writing in the naturalistic tradition, downplays the role of individuals in the economic system in this passage, other authors focus on situations where individuals are caught in a complicated web of competitive pressures that they do not fully understand. This may be done with tragedy, as in Arthur Miller's Death of a Salesman, or with poignant humor, as in Neil Simon's Prisoner of Second Avenue. The full costs-private and social-of unemployment have been recognized in a modern sense at least from the time of Steinbeck's The Grapes of Wrath and George Orwell's The Road to Wigan Pier.

Many writers seem to have a good understanding and appreciation of basic market forces, and many also recognize various aspects of market imperfections, including questions of economic stabilization. Deep concern over inflation has been expressed, as in Erich Maria Remarque's The Black Obelisk, which includes passages dealing with Germany's post-World War I hyperinflation. A delightful passage anticipating the idea of externalities can be found in Rabelais's Gargantua and Pantagruel, in which a fool adjudicates a dispute between a cook and a patron who smoked a piece of bread in the smoke rising from a goose roasting over an open fire. The cook demands equivalent compensation and is paid by the customer's money bag being shaken so that he can only hear the jingle of the coins inside.

Spillover costs were illustrated as early as Dickens's description of the pollution in Coketown in Hard Times. On the need for laws and courts to resolve disputes over property rights and to establish a legal and social framework for markets, the literature goes back at least to Shakespeare's Merchant of Venice and includes William Faulkner's The Hamlet.

As we mentioned earlier, the literary treatment of income redistribution has been recognized by several economists and has drawn some strong criticism. The presentation of this issue ranges from King Lear's brief state- 
ment that "distribution should undo excess and each man have enough" to Norris's juxtaposition of poor, starving widows' families and rich families of railroad managers (fitting the Friedmans' description of the literary stereotype). In Welcome to the Monkey House (in the Harrison Bergeron story), Kurt Vonnegut wrote a scathing piece on attempts to achieve full equality of results, and Emerson wrote in his Journals that even "odius" inequality must be borne, especially when larger incomes are earned in riskier occupations.

Concerned with more specialized government programs, Sinclair's The Jungle and Orwell's The Road to Wigan Pier lobbied effectively for government health and occupational safety regulations. Alexander Solzhenitsyn's Cancer Ward attacks many current models of socialized medicine, but it does accept some protection against catastrophic illness. Some of the novel's characters also present strong arguments against uncontrolled economic growth.

Literary writers may have anticipated, and have certainly kept pace with, the economic profession's discovery of systematic government failure. In Henry Adams's novel Democracy, the central character goes to Washington and finds fraud, corruption, and self-interest, and very little of the publicspirited trust she had expected. The professor hero of Joseph Heller's Good as Gold is never so naive, actively pursuing a plush and prestigious appointment that involves as little work as possible. Finally, however, he is repulsed and "boggled" by the sheer size and senselessness of the bureaucracy.

Much literature deals with the major private institutions of a market economy. Corporations and businesses have always come in for lighthearted treatment, from The Shoemaker's Holiday (of the early 1600s) to How to Succeed in Business Without Really Trying and How Now Dow Jones. The problem with using corporations in literary works is that they are, to use Schumpeter's terminology, rational and antiheroic. Few dramatic works are based even loosely on actual corporate histories. Some works go to idealized extremes, from Horatio Alger's "onward and upward" stories to Phillip Massinger's A New Way to Pay Old Debts. Massinger's archfiend, Sir Giles Overreach, claims to engage in a wide range of predatory practices to strengthen his monopoly. Kurt Vonnegut's RAMJAC corporation and Ian Fleming's nefarious, profit-oriented SMERSH represent the extreme of corporate world domination.

The most sustained and serious literary tradition concerning businessmen seems to have existed in the United States from the 1920s through the early 1960s, with the most active period ending with Steinbeck's The Winter of Our Discontent. In this period, business executives were often seen as "ambitious and hard-working, but with severely limited intellectual and cultural horizons"' (Brandis 1961, p. 29). The most important works in this vein are by Sinclair Lewis (Babbitt and Main Street), Arthur Miller (Death of a Salesman and All My Sons), Cameron Hawley (Executive Suite and Cash McCal), John P. Marquand (Point of No Return), and George S. Kaufman and Howard Teichmann (The Solid Gold Cadillac). 
Labor unions have received different treatment, or at least they did in the more "glamorous" and violent periods of labor organization, from the beginning of this century to the implementation of the Wagner Act of 1935. The most powerful passages come in Dos Passos, Dreiser, and Steinbeck (in The Grapes of Wrath and, especially, In Dubious Battle). More recent labor union history has not attracted such widespread literary interest-both Norma Rae and On the Waterfront deal with exceptional cases. Similarly, descriptions of terrible working conditions-like Orwell's description of coal mining in The Road to Wigan Pier-are basically obsolete. They are, however, still useful in showing employment changes caused by technological progress, the innate disutility of many kinds of work, and the importance of energy sources to the day-to-day operation of society.

Financial institutions have received very little attention in literature. The Federal Reserve System has probably never had even an important supporting role, although the devil in Goethe's Faust makes the unexpected discovery that money expansion can affect the level of national output. The Rothschilds, How Now Dow Jones, and Trading Places are perhaps the best recent examples linking drama and finance.

The classic piece on population and markets is Jonathan Swift's "A Modest Proposal." Like Kenneth Boulding's "green stamp" plan to limit population, Swift's thoughts were tied to market considerations. Swift, however, put Malthus's "positive" checks on the market, whereas Boulding's plan priced out Malthus's "preventative" checks. Swift satirically suggested that Ireland's "surplus" infants and children could be sold as food -especially to Americans who needed the nourishment and had lower culinary standards. This piece might be considered an early attack on some practitioners of political economy, and definitely as a scathing denouncement of inappropriate or inept uses of cost-benefit analysis.

In a lighter vein, some literary authors have picked up Veblen's conspicuous consumption theory, as well as the idea of a relative-income hypothesis. In J. D. Salinger's Catcher in the Rye, the young hero discovers that it is almost impossible to live with someone who has cheaper suitcases than your own. His roommate tries to cope with this threat by calling the hero's suitcases "bourgeois," but he later tries to make others believe that the suitcases belong to him. The hero moves out to take a roommate less desirable in nearly every respect, except for his luggage.

The debate on bimetallism, in spite of William Jennings Bryan's famous "cross of gold" speech, is often considered one of the dullest episodes in money and banking or economic history courses. Fortunately, Lyman Frank Baum found it an interesting topic, as did others of the period, and wrote The Wizard of $\mathrm{Oz}$ as a populist allegory on the episode. $\mathrm{Oz}$ is, of course, the abbreviation for ounce, as in an ounce of silver or gold. In Baum's work (before MGM and Judy Garland), Dorothy walks down the yellow brick (i.e., gold) road in silver, not ruby, slippers. The Scarecrow represents midwestern farmers, the Tin-man stands for urban industrial 
workers, the Wicked Witch of the East symbolizes the large industrial corporations and eastern finance, the Witch of the West is drawn from the harsh and malevolent natural forces (particularly drought) facing western farmers, the Cowardly Lion is Bryan, and the Wizard of $\mathrm{Oz}$ is the blustery but inept president of the United States. Dorothy is Baum's Everyman. ${ }^{12}$

Ideas on a "just price" or reasonable rate of profit are often raised in literature, as in the exchange between $\mathrm{Cal}$ and his father in East of Eden. It is interesting, however, that many of the authors never resolve the questions they raise. In Thomas Wolfe's From Death to Morning, the unending debate on such issues becomes the central theme of the story when the men of Old Catawba are asked to consider the fair price and profit for a mule.

It is fair to say that questions of equity and personal conflict are at the heart of most literary passages with an economic orientation. After all, literature is an exploration of the human condition and values, as seen both in everyday life and under extraordinary circumstances. Authors often put their characters in situations outside normal experience, but in good literature the intent is most often to say, or at least imply, something about all individuals and human systems in general.

Literary writers seem to agree with each other on ideas of responsible individuals who, though they may respond to economic incentives, nevertheless follow Shakespeare's Antonio and "hold the world but as the world." Another good merchant gone bad is, similarly and inevitably, punished in the third of Alexander Pope's Moral Essays, an epistle to Allen Lord Bathurst "On the Use of Riches."

The world has changed a great deal since Shakespeare and Pope, but literary characters still seek Antonio's balance even if their stages seem strangely limited when compared with those of earlier ages. The father in All My Sons finally commits suicide when he realizes that he has viewed his business interests out of all proportion. Young Benjamin in Charles Webb's The Graduate drops out of many pursuits because he does not want to believe that his future is, in one word, "plastics."

Even though many authors seem to agree on appropriate individual economic behavior, there is very little agreement on what kind of economic system would best promote that behavior, or would be most consistent with the interests of free individuals. Edward Bellamy's Looking Backward and "The Parable of the Water Tank" promote socialist forms of economic organization and cooperation, as does Percy Bysshe Shelly's "Song to the Men of England," to cite only a few examples. On the other hand, Aldous Huxley's Brave New World and Ayn Rand's The Fountainhead and Atlas Shrugged offer eloquent defenses of conservative ideas on individual freedom, growth, and economic efficiency. Moreover, both these authors warn of abuses when economic and political power are concentrated and held by different kinds of public agencies. These arguments, from the right and the left, should sound familiar to economists-exactly the same points have been argued in the professional economic literature for over a hundred years. 


\section{CONCLUSIONS}

For economists interested in using literary passages in their teaching and writing, the diversity of passages cited above should provide sufficient promise that acceptable material is available on most topics. Literary authors and their works are no more homogeneous than economists and their works. Like economists, literary authors vary in political beliefs, the depth and breadth of their economic understanding, and even in writing skills. Literary authors are especially important to economists in so far as they, like Keynes's defunct economists, sometimes influence public and scholarly attitudes toward economic issues (Stigler 1982, pp. 1-50).

It is hardly surprising that such an extensive and diverse set of literary materials on economic themes should be available. Most social observers, including literary authors of both serious and more commercial works (Beaumont and Fletcher in Shakespeare's time; Jacqueline Suzanne and soap opera scriptwriters in ours), accept economics as an important part of the social fabric, and they face markets that are segmented into groups of consumers with different incomes, educational backgrounds, political leanings, and economic interests. At least since the Renaissance-when printed works began to appear in native languages as well as in Latin, and when more people began to acquire formal education-authors with different perspectives on economic and social relationships have found markets for their ideas. Literary diversity develops because any work-even Shakespeare's, which Ben Jonson recognized as "not of an age but for all time"-is strongly influenced by the life and times of its author.

The one area where literary works generally fail to provide useful materials for economists is in the development of a complex set of interrelated economic actions and consequences. Some writers, like Rand and Bellamy, have tried to capture the effects that market-oriented economists see in the workings of Adam Smith's invisible hand, or the "inevitable consequences" that many antimarket economists attribute, following Karl Marx, to the concentrated ownership of the means of production. These attempts are rarely completely successful on any level, particularly on the promarket side where even many sympathetic authors have apparently not understood the idea of using markets to channel potentially antisocial behavior into useful and productive outlets while maintaining high levels of personal freedom for those who are well intentioned.

Is it more than coincidence that the authors who produce works that attempt to capture a full understanding of any economic system seem to attract small numbers of fiercely loyal readers? Whatever the case, the job of explaining how economic concepts are interrelated and how economic systems work and can be evaluated on the important (but admittedly narrow) basis of economic efficiency still falls almost exclusively to economists and economic educators. On many other important topics, however, there are reasonable opportunities for cross-disciplinary work with those who specialize in literature and drama. 


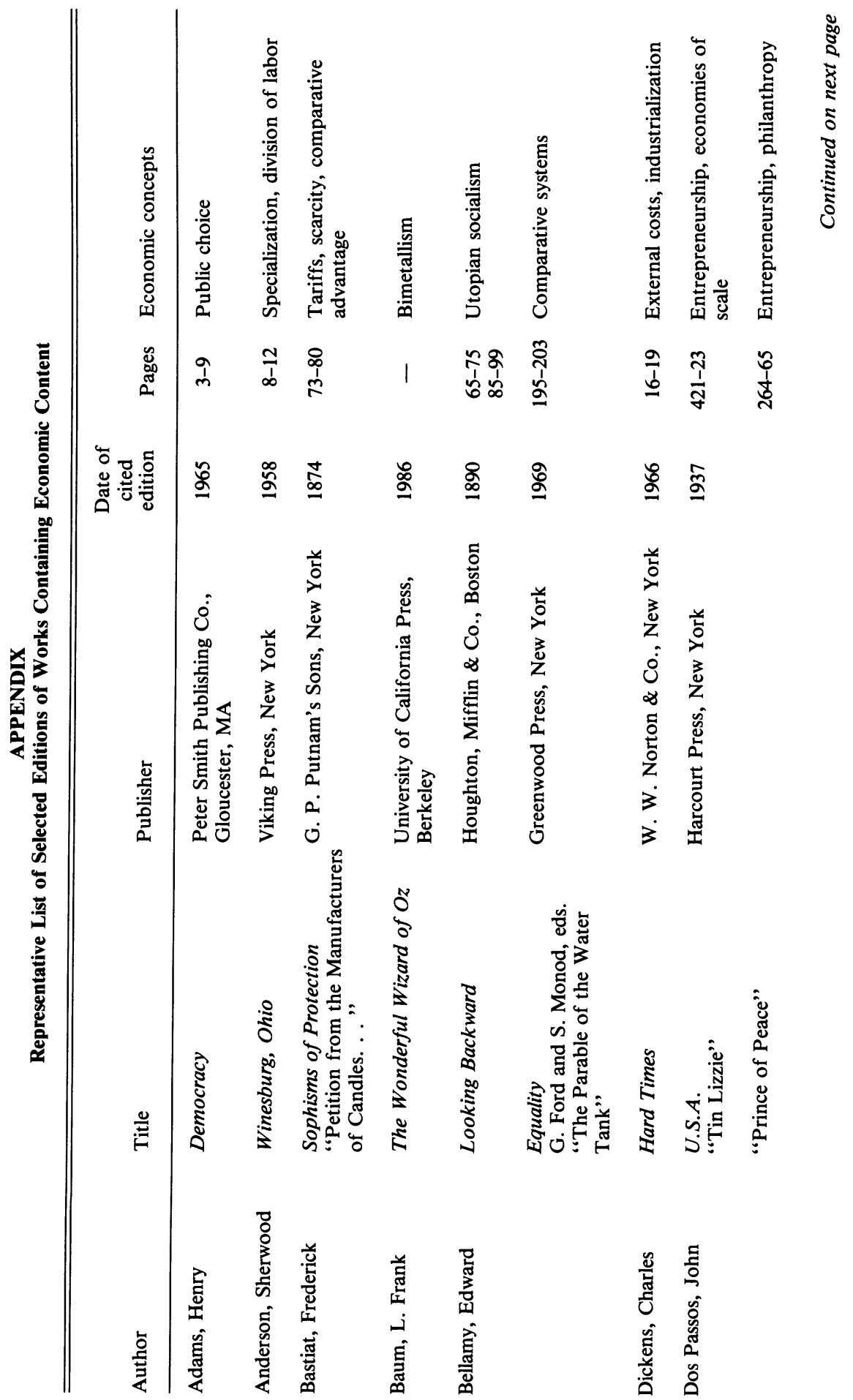




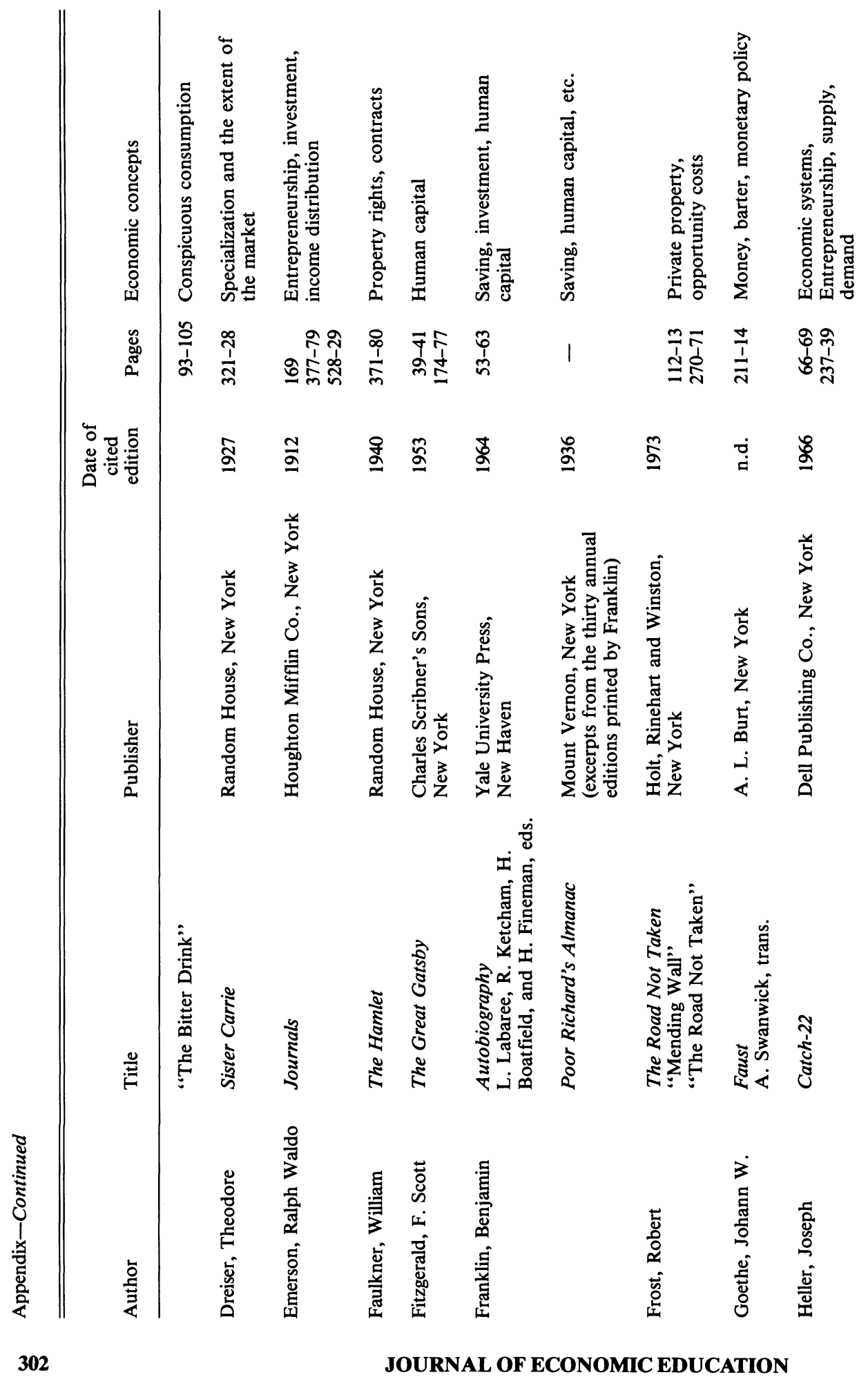




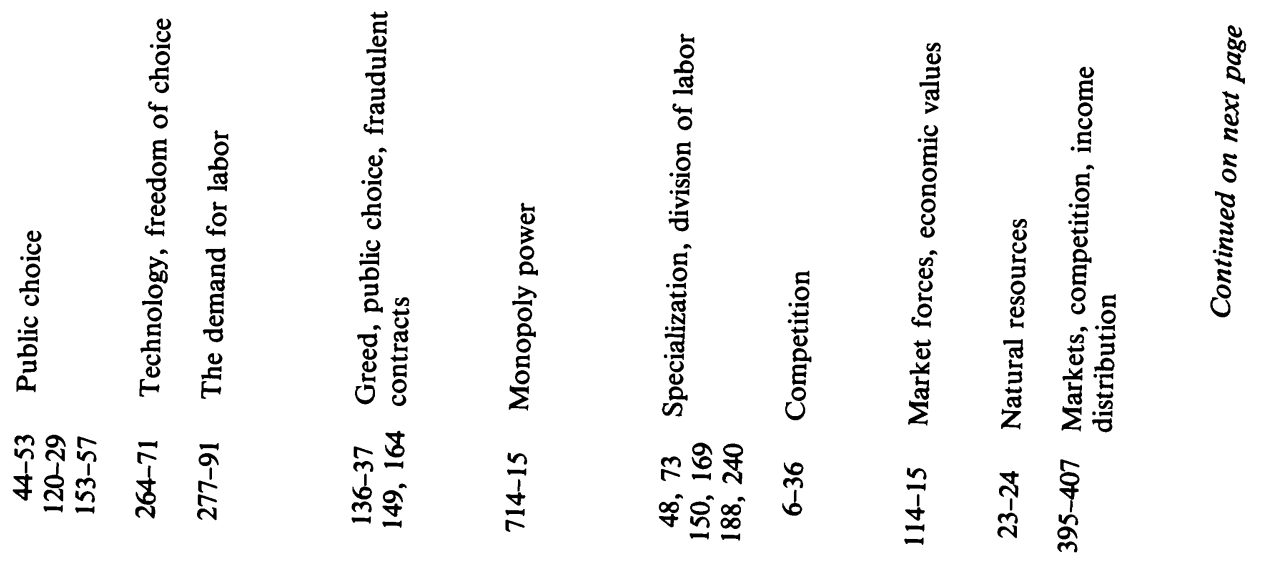
$\stackrel{8}{g}$
$\Xi \quad \bar{g}$

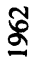

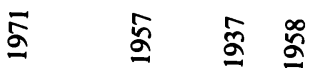

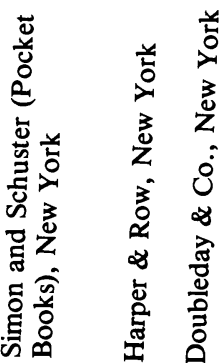

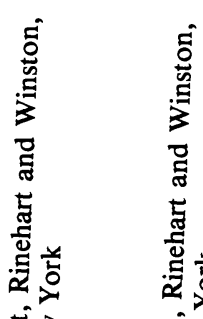

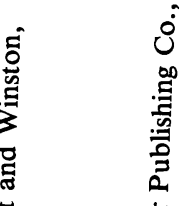

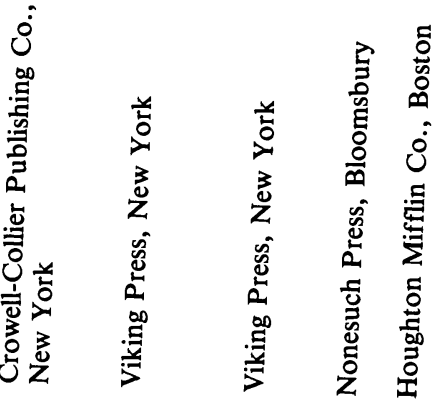

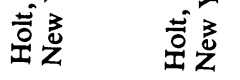

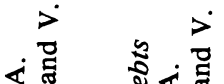

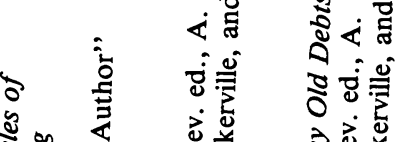

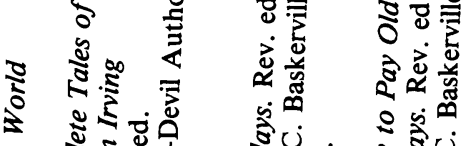

竞

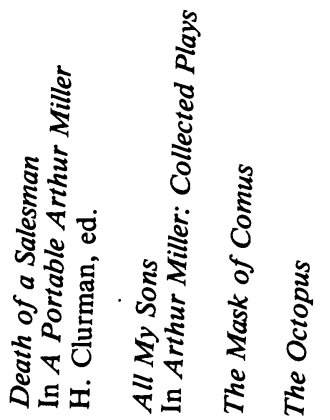

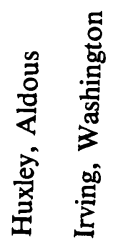

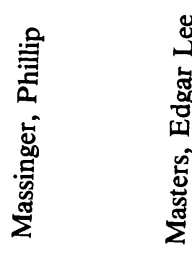

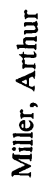

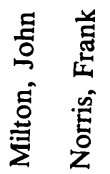

Summer 1989 


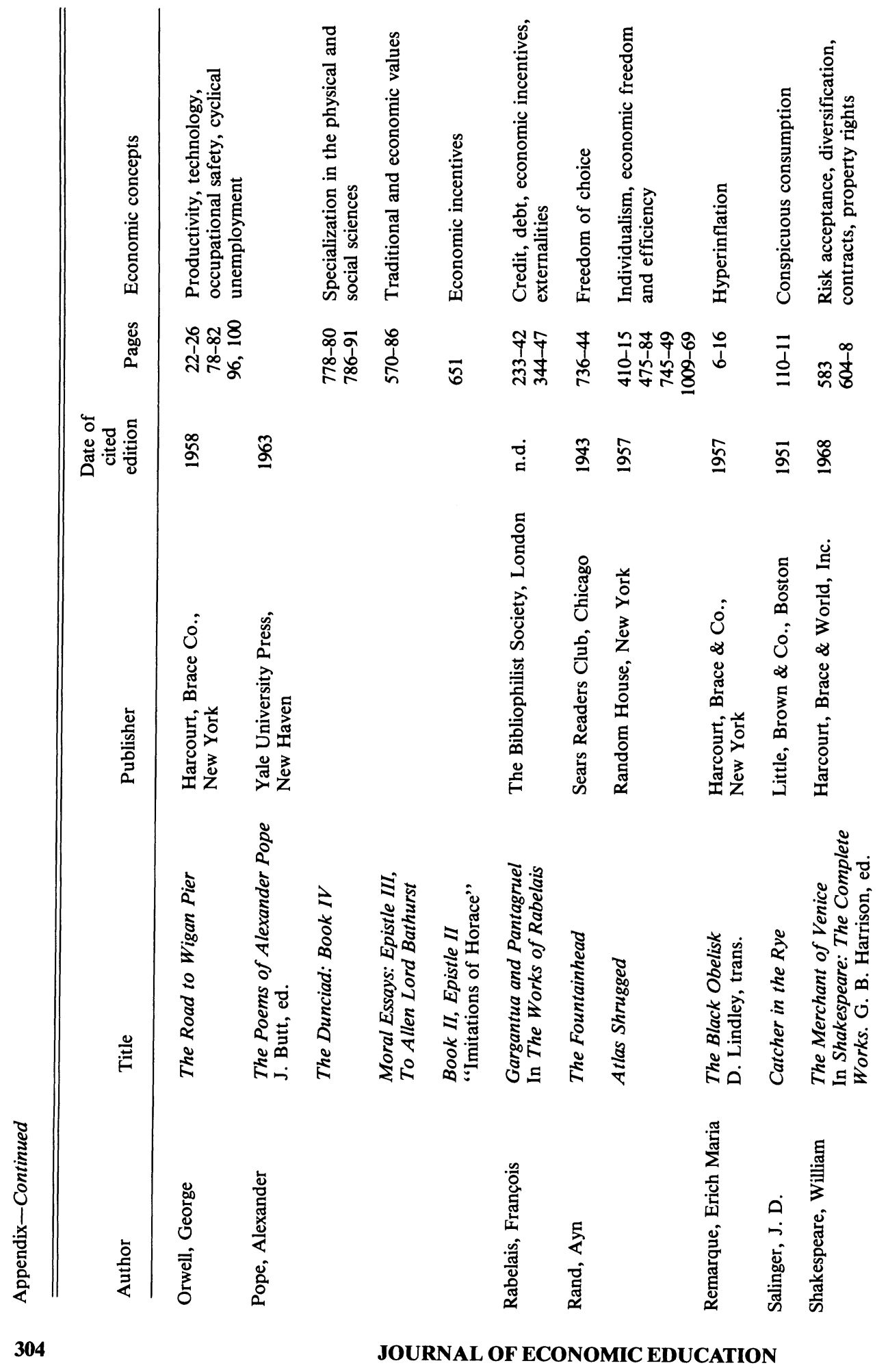




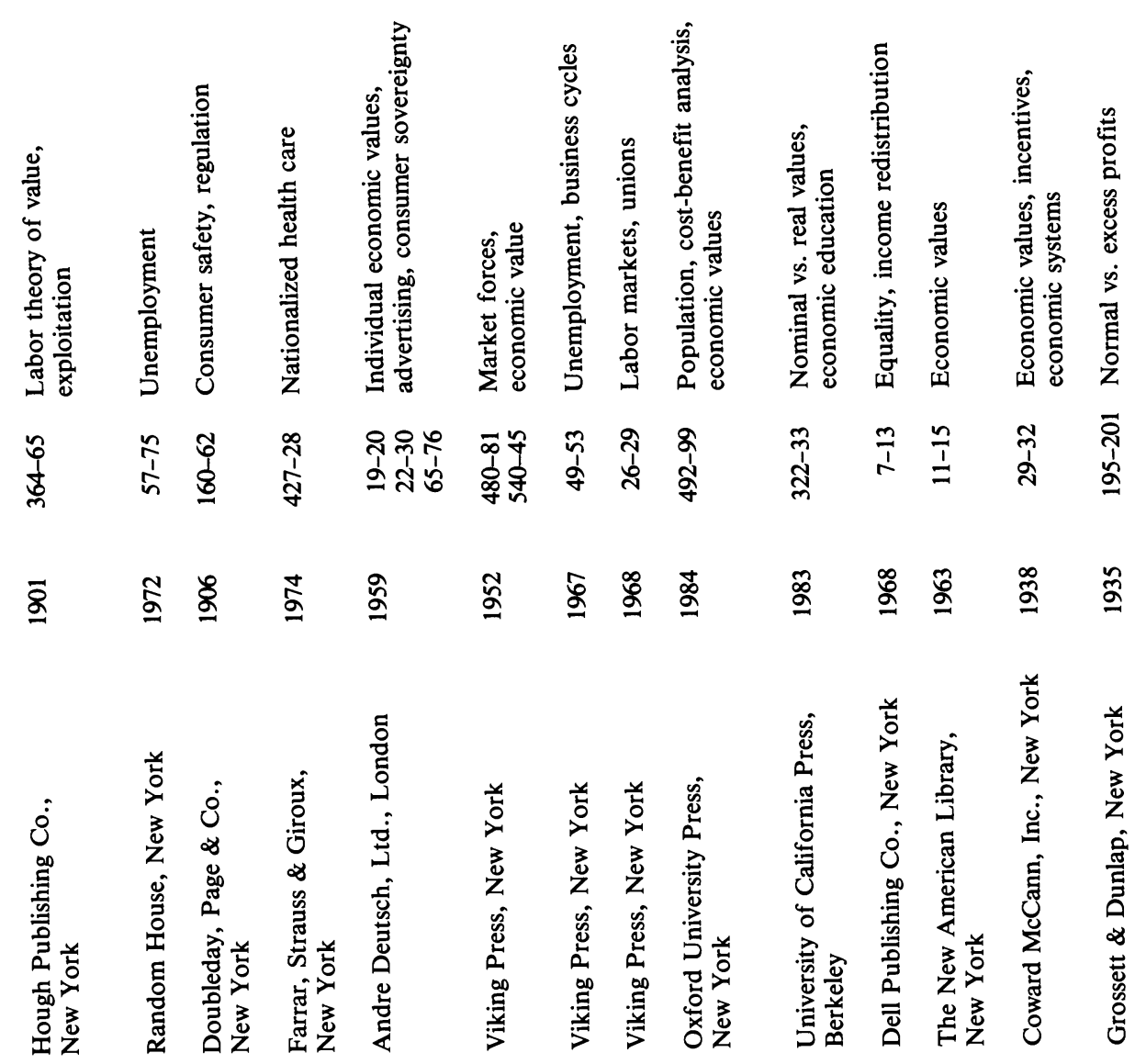

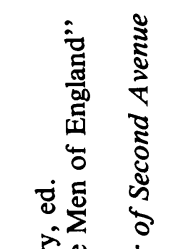

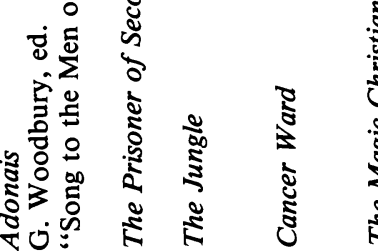

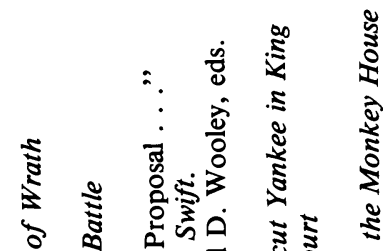

- 0 क

ปั

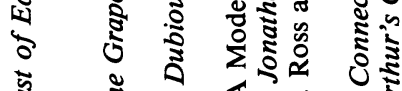

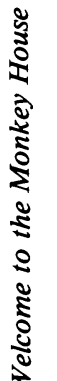

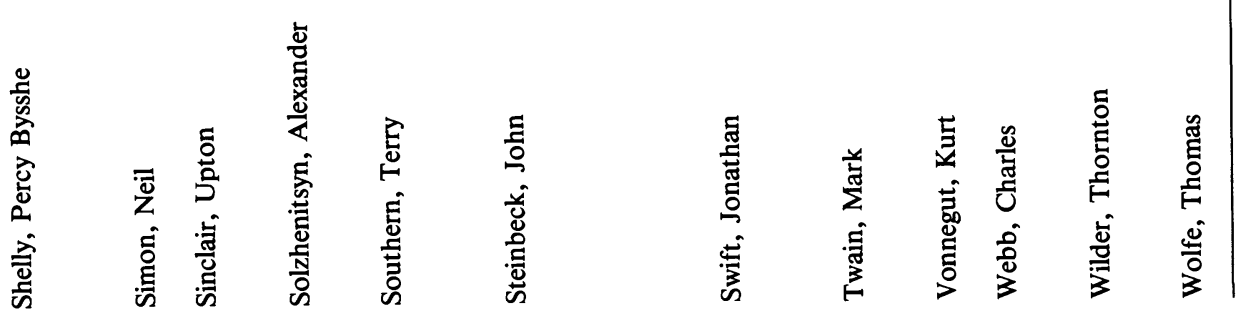




\section{NOTES}

1. Joseph Schumpeter introduced several of these ideas in his well-known works, Capitalism, Socialism and Democracy and the History of Economic Analysis. As discussed elsewhere in the paper, Milton Friedman, George Stigler, and others have recently echoed those thoughts. On language, see Neale (1982).

2. When Jacob Marschak was organizing the program for the 1977 Annual Meeting of the American Economic Association, he designated three main themes, including "the boundaries of economics, with several sessions on how economics has related and might relate to other scientific and humanistic disciplines." (Editor's Introduction, American Economic Review, May 1978, p. viii)

3. The Friedmans refer specifically to the influence of Edward Bellamy's Looking Backward and approvingly cite the satirical comments on equality of the Dodo from Lewis Carroll's Alice in Wonderland. Also see their video program, "Created Equal," from the television series.

4. Such themes often appeared in the popular (and profit-oriented) drama of this period; see Knights (1968).

5. For an introduction to this debate, and for numerous references, see Jefferson (1972) and Aydelotte (1948).

6. See Grampp (1973) and, from a literary viewpoint, Scudder (1899).

7. As professor emeritus, Farnam published Shakespeare's Economics (1931). For a literary perspective on Shakespeare's use of economic imagery, see Heilman (1968).

8. For example, see Paul and Ronald Wonnacott (1979, p. 676), which reprints the passage from Kurt Vonnegut's Welcome to the Monkey House discussed below.

9. Passages cited in this article that have previously appeared in this fashion include excerpts from Twain's A Connecticut Yankee in King Arthur's Court (vol. 84, no. 6), Pope's Moral Essays (vol. 85, no. 4), Solzhenitsyn's Cancer Ward (vol. 85, no. 5), Rabelais's Gargantua and Pantagruel (vol. 87, no. 1), and Goethe's Faust (vol. 94, no. 1).

10. Units on economic concepts in children's literature, George Orwell's Animal Farm, and Arthur Miller's Death of a Salesman have been printed in the annual Economic Education Experiences of Enterprising Teachers, available from the Joint Council on Economic Education in New York.

11. See, for example, the passages on Davis Matlock, Walter Simmons, "Butch" Weldy, Schroeder the Fisherman, Eugene Carman, and "Ace" Shaw.

12. For a detailed description of the allegorical content in The Wonderful Wizard of $\mathrm{Oz}$, see Littlefield (1964).

\section{REFERENCES}

Aydelotte, W. O. 1948. The England of Marx and Mill as reflected in fiction. Journal of Economic History, supplement 8, The Tasks of Economic History, 42-58.

$\rightarrow$ Becker, G. 1977. Reply to Hirshliefer and Tullock. Journal of Economic Literature 15:506-7.

Brandis, R. 1961. The American writer views the American businessman. Quarterly Review of Economics and Business 1:29-38.

Farnam, H. W. 1931. Shakespeare's economics. New Haven: Yale University Press.

Friedman, M., and R. Friedman. 1980. Free to choose. New York: Harcourt Brace and Jovanovich.

Galbraith, J. K. 1963. The McLandress dimension. Boston: Houghton Mifflin.

Grampp, W. D. 1973. Classical economics and its moral critics. History of Political Economy 5:359-74.

Heilman, R. B. 1968. The economics of Iago and others. Publications of the Modern Language Association 19:81-85.

Hirshliefer, J. 1977. Shakespeare vs. Becker on altruism: The importance of having the last word. Journal of Economic Literature 15:500-502.

Jefferson, M. 1972. Industrialization and poverty: In fact and fiction. In The long debate on poverty. London: Institute of Economic Affairs.

Jevons, M. 1977. Murder at the margin. Sun Lakes, AZ: Thomas Horton and Daughters.

Knights, L. C. 1968. Drama and society in the age of Jonson. New York: W. W. Norton (first published in 1937).

$\rightarrow$ Littlefield, H. M. 1964. The Wizard of Oz: Parable on populism. American Quarterly 16: 47-58. 
Neale, W. C. 1982. Language and economics. Journal of Economic Issues 16:355-69.

Norris, F. 1958. The octopus. Edited by Kenneth S. Lynn. Cambridge, MA: Riverside Press (first published in 1901).

Schumpeter, J. A. 1942. Capitalism, socialism and democracy. New York: Harper \& Row. - 1954. History of economic analysis. New York: Oxford University Press.

Scudder, V. D. 1899. Social ideas in English letters. Boston: Houghton, Mifflin and Co.

Spiegel, H. W. 1971. The growth of economic thought. Englewood Cliffs: Prentice-Hall.

Stigler, G. J. 1982. The economist as preacher and other essays. Chicago: University of Chicago Press.

Wonnacott, P., and R. Wonnacott. 1979. Economics. New York: McGraw-Hill. 